\title{
Effect of Intravenous Insulin-like Growth Factor I in Two Patients with Leprechaunism
}

\author{
PHILIPPE F. BACKELJAUW, ${ }^{1}$ CRESIO ALVES, MARGARET EIDSON, \\ WILLIAM CLEVELAND, LOUIS E. UNDERWOOD, AND MARSHA L. DAVENPORT \\ Department of Pediatrics, University of North Carolina, Chapel Hill, North Carolina 27599-7220 \\ [P.F.B., L.E.U., M.L.D.], and Department of Pediatrics, University of Miami, Miami, \\ Florida 33101 [C.A., M.E., W.C.]
}

\begin{abstract}
ABSI
Leprechaunism (Donohue syndrome) is an autosomal
recessive disorder characterized by hyperglycemia, ex-
treme insulin resistance, dysmorphic features, failure to
thrive, and early death. In this study, recombinant IGF-I,
which has both insulin-like and anabolic effects, was ad-
ministered to two infants with leprechaunism in an attempt
to reduce hyperglycemia and improve nutritional status.
IGF-I was infused for $66 \mathrm{~h}$ in patient FL-1 and $62 \mathrm{~h}$ in
patient NC-2, with maximal infusion rates of 110 and 40
$\mu \mathrm{g} / \mathrm{kg} / \mathrm{h}$, respectively. Although supraphysiologic concen-
trations of IGF-I were achieved (459 and $1583 \mu \mathrm{g} / \mathrm{L}$ in FL-1
and NC-2, respectively), there were no apparent glucose-
lowering or nitrogen-sparing effects. Insulin concentrations
decreased from extremely high values $(16804$ and 10224
pmol/L) but remained elevated (611 pmol/L in FL-1 and
\end{abstract}
\section{IBSTRACT}

Leprechaunism (Donohue syndrome), a genetic disorder characterized by extreme insulin resistance, intrauterine growth retardation, dysmorphic features, and lipoatrophy (1-3), is associated with defects in insulin binding, insulin receptor autophosphorylation, and kinase activity (4). Various point mutations in the insulin receptor gene have been identified in affected patients $(5$, 6 ), and some patients also have functional abnormalities of receptors for IGF-I and epidermal growth factor (7-9). Variations in defects of the insulin receptor and receptor signaling mechanisms may explain the phenotypic heterogeneity of the leprechaunism syndrome, with some pa-

Received February 15, 1994; accepted July 6, 1994.

Correspondence: Philippe F. Backeljauw, M.D., Division of Pediatric Endocrinology, University of North Carolina, CB\#7220, 509 Burnett-Womack, Chapel Hill, NC 27599.

Supported by Training Grant DK-07129 and Research Grants HD-26871 and HD-28447 from the National Institutes of Health. The Clinical Research Center of the University of North Carolina and of the University of Miami are supported by grants (RR-00046 and MOI-IR05280, respectively) from the General Clinical Research Centers Program, Division of Research Resources, National Institutes of Health.

${ }^{1}$ Presently at the Department of Pediatrics, Carolinas Medical Center, Charlotte, NC 28203.
$5869 \mathrm{pmol} / \mathrm{L}$ in NC-2). No changes in serum and urinary urea nitrogen or electrolytes occurred. IGF binding protein-2, which was the predominant IGF binding protein in serum by ligand blot and immunoblot, did not change with IGF-I infusion. IGF binding protein-3 levels were low at baseline and increased slightly during the infusion. We hypothesize that the lack of significant glucose-lowering and anabolic responses to IGF-I could be secondary to a postreceptor defect in IGF-I signaling resulting from the absence of functional insulin receptors. (Pediatr Res 36: 749-754, 1994)

GH, growth hormone

\section{Abbreviations}

IGFBP, insulin-like growth factor binding protein tients surviving for several years and others dying in early infancy.

IGF-I is structurally similar to insulin, and IGF-I receptors are homologous with insulin receptors, with which they form hybrid receptors. IGF-I has glucoselowering as well as anabolic actions: it mediates most of the growth-promoting actions of $\mathrm{GH}$, causes weight gain in hypophysectomized rats $(10,11)$, and is anabolic in humans with GH insensitivity syndrome (12) and calorierestricted normal volunteers (13). We therefore examined the short-term metabolic effects of IGF-I administered i.v. in two patients with leprechaunism to determine whether this peptide might serve as a substitute for insulin in these patients by reducing blood glucose and producing an anabolic response.

\section{METHODS}

Patient FL-1 is a white female who was the product of a nonconsanguineous marriage and a 37-wk unremarkable pregnancy, labor, and delivery. Her birth weight was $1.8 \mathrm{~kg}$, length $44.5 \mathrm{~cm}$, and head circumference $30 \mathrm{~cm}$ (all $<5$ th percentile). At $3 \mathrm{wk}$ of age, she was observed to 
have hyperglycemia $(23.4 \mathrm{mmol} / \mathrm{L}$ or $422 \mathrm{mg} / \mathrm{dL})$; decreased fat stores; a small, triangular face; a depressed nasal bridge; a small mandible; thick lips; and gingival hyperplasia. She had breast tissue hyperplasia, a distended abdomen without organomegaly, a prominent clitoris and prominent labia majora, and generalized hirsutism. An echocardiogram, obtained to investigate a heart murmur, showed left ventricular hypertrophy and a small atrial septal defect. Ultrasonography of the pelvic area demonstrated bilateral ovarian cysts. A randomly obtained blood sample revealed an extremely elevated insulin concentration of $2870 \mathrm{pmol} / \mathrm{L}$ (normal 35-145 $\mathrm{pmol} / \mathrm{L}$ ) and a C-peptide of $20 \mu \mathrm{g} / \mathrm{L}$ (normal $0.8-4.0$ $\mu \mathrm{g} / \mathrm{L}$ ). IGF-I serum concentration was $7.5 \mu \mathrm{g} / \mathrm{L}$ (normal $17-248 \mu \mathrm{g} / \mathrm{L}$ ) and glycosylated $\mathrm{Hb} 7.3 \%$ (normal 4.6$7.3 \%$ ).

During the second month of life, neither several days of s.c. administration of exogenous regular insulin (maximum $10 \mathrm{U} / \mathrm{kg} / \mathrm{d}$ ), nor i.v. infusion of insulin (maximum rate of $1.4 \mathrm{U} / \mathrm{kg} / \mathrm{h}$ ) lowered blood glucose. On a lowcarbohydrate diet, her glucose concentrations were 5.6$16.7 \mathrm{mmol} / \mathrm{L}(100-300 \mathrm{mg} / \mathrm{dL})$. During her first 6 months of life she had worsening hirsutism, rectal prolapse, gastroesophageal reflux and slow growth with delayed mental and motor development. She received the trial of recombinant IGF-I at 8 mo of age.

Patient NC-2 is of Afghani descent and was the product of first cousins and a 38-wk pregnancy complicated by insulin-dependent gestational diabetes. His birth weight was $1.53 \mathrm{~kg}$, length $42 \mathrm{~cm}$, and head circumference $32 \mathrm{~cm}$ (all $<5$ th percentile). He had a small face with prominent eyes, wide nostrils, large ears, thick lips with prominent rugae, a small chin, and increased facial hair. He had prominent breast tissue and a distended abdomen with poorly developed abdominal wall musculature. As part of an evaluation for a cardiac murmur, an ECG showed left ventricular hypertrophy, and an echocardiogram demonstrated subaortic stenosis and mild mitral regurgitation. He had cholestatic jaundice with fat malabsorption, hepatomegaly, and rectal prolapse. His phallus was enlarged $(4.4 \mathrm{~cm}$ stretched; mean $\pm \mathrm{SD}$ for term male is 3.5 $\pm 0.4 \mathrm{~cm})$. He had hyperpigmented, loose, wrinkled skin; generalized hypertrichosis; acanthosis nigricans in the cervical, axillary, and inguinal regions; and dysplastic nails. While receiving continuous nasogastric tube feedings to avoid fasting hypoglycemia, his glucose concentration ranged between 11 and $16 \mathrm{mmol} / \mathrm{L}(200-300 \mathrm{mg} /$ dL). Measured insulin concentrations were 8 093, 12650 , and $15943 \mathrm{pmol} / \mathrm{L}$ (normal 35-145 pmol/L). IGF-I concentrations were extremely low, ranging between 2 and 3 $\mu \mathrm{g} / \mathrm{L}$. Exogenous regular insulin, at a maximum dose of 1 $\mathrm{U} / \mathrm{kg}$ i.v. given $5 \mathrm{~d}$ before the IGF-I trial, did not influence serum glucose values $(14.0 \mathrm{mmol} / \mathrm{L}$ at baseline and $13.0,13.3,13.6$, and $12.8 \mathrm{mmol} / \mathrm{L}$ at $15,30,45$, and 60 min, respectively).

When given IGF-I at 5 mo of age, his length $(52.5 \mathrm{~cm})$ and weight $(3.57 \mathrm{~kg})$ were below the 5 th percentile, although height velocity and head growth were close to normal. Molecular analyses of skin fibroblasts indicated that he is homozygous for a deletion of both alleles of the insulin receptor gene (14).

The experimental protocols were approved by the Committees for the Protection of the Rights of Human Subjects at the University of Miami and the University of North Carolina at Chapel Hill, and written, informed consent was obtained from the parents.

Patient FL-1 was given a 5\% dextrose solution i.v. at $25 \%$ of the maintenance rate. Her oral intake of formula was $180-190 \mathrm{kcal} / \mathrm{kg} / \mathrm{d}$. Blood for baseline studies was obtained, and capillary glucose concentrations were determined every $3 \mathrm{~h}$ (Chemstrip BG, Accu-Check II, Boehringer-Mannheim, Indianapolis, IN). After $4 \mathrm{~d}$, a continuous i.v. infusion of recombinant human IGF-I (gift from Genentech Inc., South San Francisco, CA) diluted in physiologic saline was begun at a dose of $4 \mu \mathrm{g} / \mathrm{kg} / \mathrm{h}$ and increased every $4 \mathrm{~h}$ by $10 \mu \mathrm{g} / \mathrm{kg} / \mathrm{h}$ (if glucose levels did not fall below $5.6 \mathrm{mmol} / \mathrm{L}$ ) to a maximal infusion rate of $110 \mu \mathrm{g} / \mathrm{kg} / \mathrm{h}$. Blood glucose concentrations were monitored every $1-2 \mathrm{~h}$ during the infusion. Serum electrolytes, urea nitrogen, creatinine, insulin, IGF-I, IGF-II, IGFBP, and $\mathrm{GH}$ were measured daily. Twenty-four-hour urine collections were obtained for measurement of excretion of urea nitrogen, creatinine, and electrolytes. Glucose, serum and urinary electrolytes, urea nitrogen, and creatinine were measured by standard automated techniques. Serum concentrations of IGF-I and IGF-II were measured by RIA after the binding proteins were removed by C-18 Sep-pak extraction (Waters Associates, Milford, MA) $(15,16)$. Serum GH (Nichols Institute, San Juan Capistrano, CA) and insulin (Binax Corp., South Portland, ME) were measured by RIA from kits. Ligand blotting was performed for evaluation of IGFBP as previously described (17). Serum was subjected to SDSPAGE under nonreducing conditions, transferred to nitrocellulose paper, and incubated overnight with a mixture of [125]IGF-I and [125]IGF-II (18). IGFBP were visualized by autoradiography and quantified by scanning densitometry. Some filters were also immunoblotted with antiserum to IGFBP-2 (provided by Dr. David R. Clemmons, University of North Carolina) as previously described (19). Antibody binding was visualized using an alkaline phosphatase-conjugated antibody detection system (Promega Corp., Madison, WI).

Patient NC-2 was fed formula continuously through a nasogastric tube, receiving $230 \mathrm{kcal} / \mathrm{kg} / \mathrm{d}$. After $4 \mathrm{~d}$ of observation, recombinant human IGF-I (Genentech) diluted in physiologic saline was infused at gradually increasing doses over a 48-h period to a dose of $40 \mu \mathrm{g} / \mathrm{kg} / \mathrm{h}$. Capillary glucose concentrations were measured using a One Touch II glucometer system (Lifescan Inc., Milpitas, CA). Blood was collected at 0900 and $2100 \mathrm{~h}$ daily for measurement of serum glucose, urea nitrogen, creatinine, electrolytes, insulin, IGF-I, IGF-II, IGFBP, and $\mathrm{GH}$. Urine electrolytes, urea nitrogen, and creatinine were also determined. Ligand blot and immunoblot anal- 
yses of the IGFBP were performed using plasma samples.

\section{RESULTS}

The IGF-I infusion in patient FL-1 ended after $66 \mathrm{~h}$ when venous access was lost. At that time, she had received IGF-I at a maximal rate of $110 \mu \mathrm{g} / \mathrm{kg} / \mathrm{h}$ for $2 \mathrm{~h}$ (Fig. 1, top panel). Caloric intake, urinary output, and body weight $(4.8 \mathrm{~kg})$ did not change. The IGF-I infusion in patient NC-2 was stopped after $62 \mathrm{~h}$ because he developed congestive heart failure, most likely secondary to fluid and salt overload superimposed on his hypertrophic cardiomyopathy. His weight had increased from 3.57 to $3.90 \mathrm{~kg}$, and he showed pitting edema in the dependent areas. The maximum infusion rate in this child was 40 $\mu \mathrm{g} / \mathrm{kg} / \mathrm{h}$ (Fig. 2, top panel).

Serum IGF-I concentrations in FL-1 increased from a low baseline value of $7.5 \mu \mathrm{g} / \mathrm{L}$ to a maximum of 459.0 $\mu \mathrm{g} / \mathrm{L}$ on the second day of infusion and returned to 9.2 $\mu \mathrm{g} / \mathrm{L}$ within $24 \mathrm{~h}$ after the IGF-I infusion was stopped
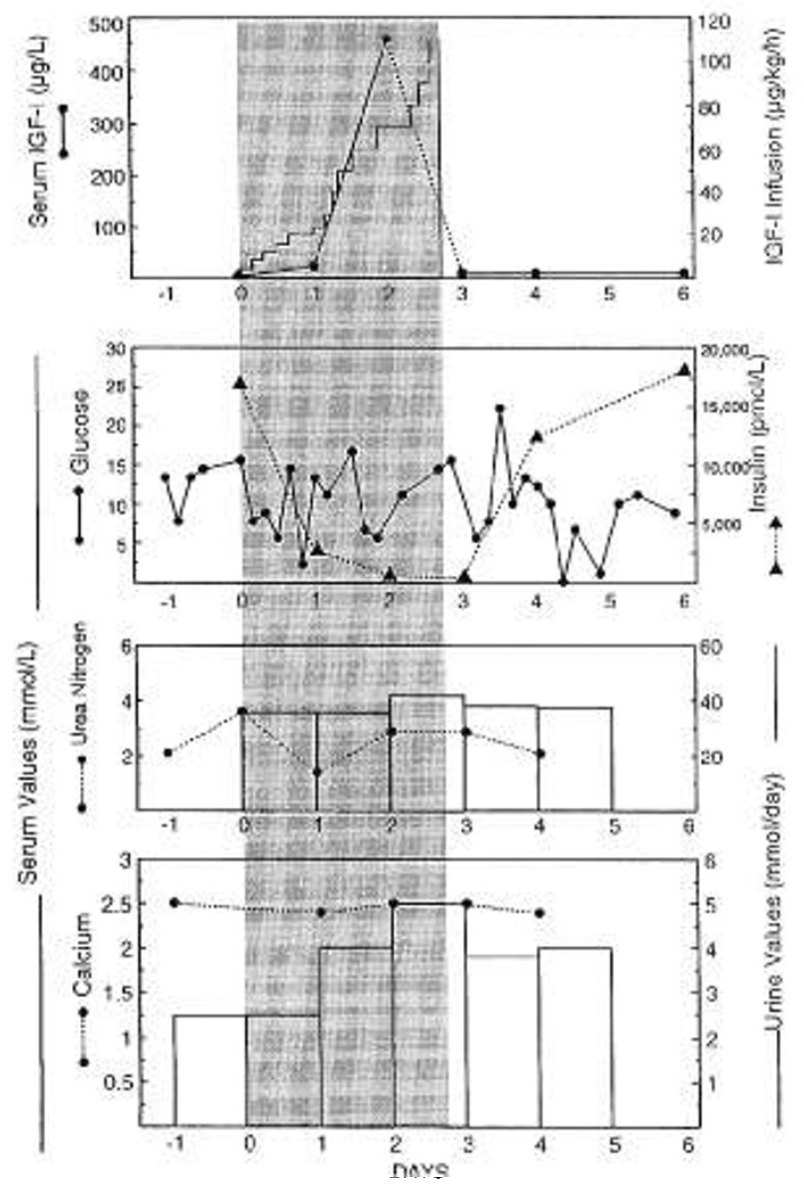

Figure 1. IGF-I infusion rates (bar graph in top panel) and serum concentrations of IGF-I, glucose, insulin, urea nitrogen, and calcium and 24-h urinary excretion of urea nitrogen and calcium in FL-1. The urine values are depicted by bars. The shaded area represents the IGF-I infusion period. Achievement of supraphysiologic serum IGF-I concentrations did not cause a decline in blood glucose values. In contrast, serum insulin concentrations decreased. The IGF-I infusion did not cause a sustained decrease in serum urea nitrogen or urinary urea nitrogen excretion.
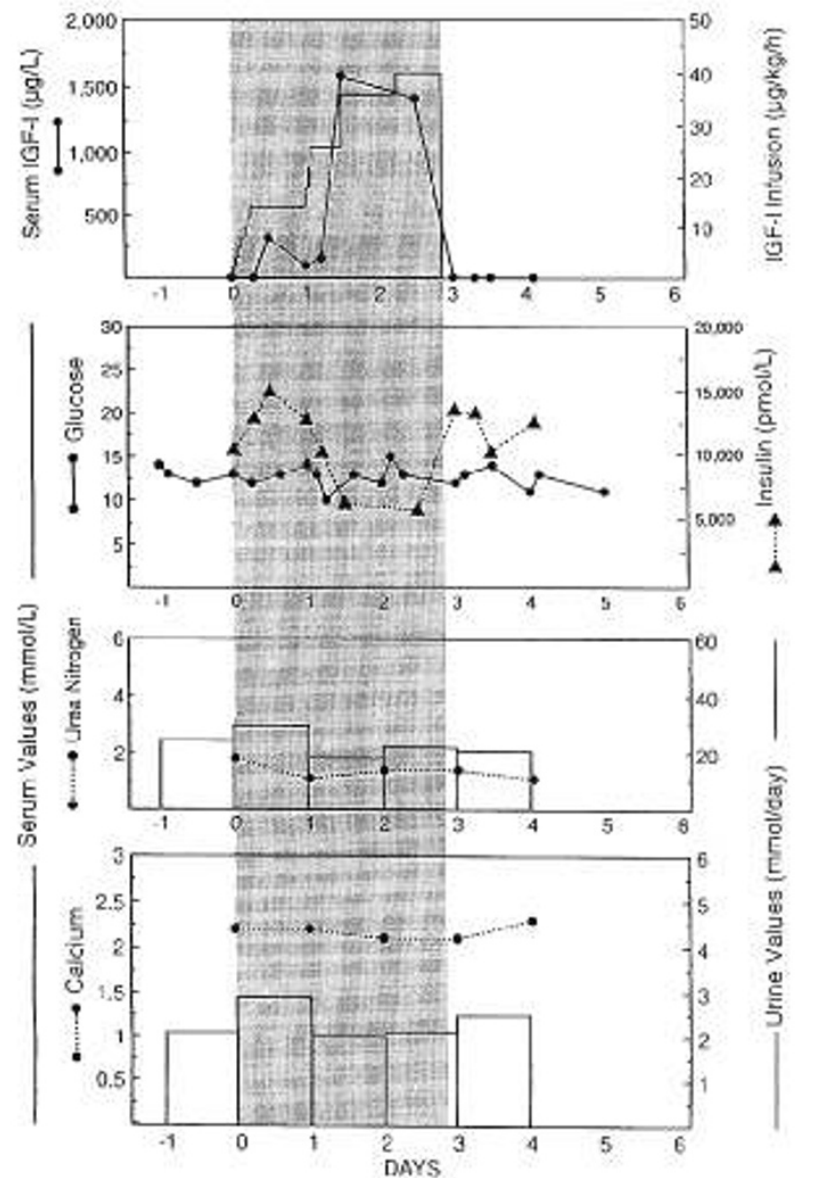

Figure 2. IGF-I infusion rates and serum concentrations of IGF-I, glucose, insulin, urea nitrogen, and calcium and 24-h urinary excretion of urea nitrogen and calcium in NC-2. The urine values are depicted by bars. The shaded area represents the IGF-I infusion period. Achievement of supraphysiologic serum IGF-I concentrations did not cause the blood glucose to decline, but insulin levels decreased to $40 \%$ of maximum values during the IGF-I infusion and rose to pretreatment levels after its discontinuation. The IGF-I infusion did not cause a change in either serum urea nitrogen or urinary urea nitrogen, nor did it affect the serum calcium concentration or urinary calcium excretion.

(Fig. 1, top panel). Serum IGF-II levels were $240.0 \mu \mathrm{g} / \mathrm{L}$ at baseline (normal $419.0 \pm 145.0 \mu \mathrm{g} / \mathrm{L}$ ), decreased to $84.0 \mu \mathrm{g} / \mathrm{L}$ after $2 \mathrm{~d}$ of infusion, and returned to baseline values $(300.0 \mu \mathrm{g} / \mathrm{L})$ within $6 \mathrm{~h}$ of discontinuation of infusion. Although frequent sampling of $\mathrm{GH}$ was not possible, daily $\mathrm{GH}$ levels did not change $(<0.6 \mu \mathrm{g} / \mathrm{L}$ before, during, and after the IGF-I infusion). In NC-2, serum IGF-I concentrations were 2.3 and $2.9 \mu \mathrm{g} / \mathrm{L}$ at baseline, increased to $1583.0 \mu \mathrm{g} / \mathrm{L}$ at the maximal infusion rate $(40$ $\mu \mathrm{g} / \mathrm{kg} / \mathrm{h}$ ), and decreased to baseline within $12 \mathrm{~h}$ after the infusion was stopped (Fig. 2, top panel). Baseline IGF-II values decreased from 97.0 and 166.0 (mean 132.0) $\mu \mathrm{g} / \mathrm{L}$ to $44.0 \pm 25.0 \mu \mathrm{g} / \mathrm{L}$ during the infusion and returned to baseline range within $12 \mathrm{~h}$ after discontinuation of infu$\operatorname{sion}(129.0 \pm 24.0 \mu \mathrm{g} / \mathrm{L})$. GH levels were not affected by the infusion $(<0.7 \mu \mathrm{g} / \mathrm{L})$.

Effects on carbohydrate metabolism. Despite achieving supraphysiologic concentrations of IGF-I, blood glucose levels were not significantly altered in either patient. 
FL-1 experienced wide fluctuations in glucose values before and during the IGF-I infusion. Hyperglycemia was noted after each feeding. Blood glucose concentrations were more stable in $\mathrm{NC}-2$, who received constant enteral feedings, but all values were above normal [9.7-15.8 $\mathrm{mmol} / \mathrm{L}(174$ to $284 \mathrm{mg} / \mathrm{dL})]$. Insulin concentrations decreased from a pretreatment value of $16804 \mathrm{pmol} / \mathrm{L}$ to $611 \mathrm{pmol} / \mathrm{L}$ in FL-1 and from 10224 to $5869 \mathrm{pmol} / \mathrm{L}$ in NC-2. Within $24 \mathrm{~h}$ after discontinuing IGF-I, the insulin concentrations rose to preinfusion values (Figs. 1 and 2, second panel).

Anabolic effects. Infusion of IGF-I did not exert anabolic effects in either patient; no decrease in serum urea nitrogen or urinary urea nitrogen excretion was observed (Figs. 1 and 2, third panel). Although serum calcium did not change, the urinary excretion of calcium increased on the second day of the IGF-I infusion in FL-1 and remained elevated postinfusion. No change in serum or urinary calcium was observed in NC-2 (Figs. 1 and 2, lower panel). No changes were observed in serum and urinary electrolytes or in creatinine clearance in either patient.

IGFBP. By ligand blot analysis, the predominant IGFBP in the serum or plasma of both patients exhibited an $\mathbf{M}_{\mathrm{r}}$ of approximately 32000 (Fig. 3). This band immunostained, with intensity comparable to the ligand blot signal, with a specific antibody raised against human IGFBP-2, making its identity likely IGFBP-2 (data not shown). A lighter band apparent at $M_{r} 45000$ is consistent with IGFBP-3. Densitometric analyses of the ligand blots revealed no consistent changes in the $32000-\mathrm{M}_{\mathrm{r}}$
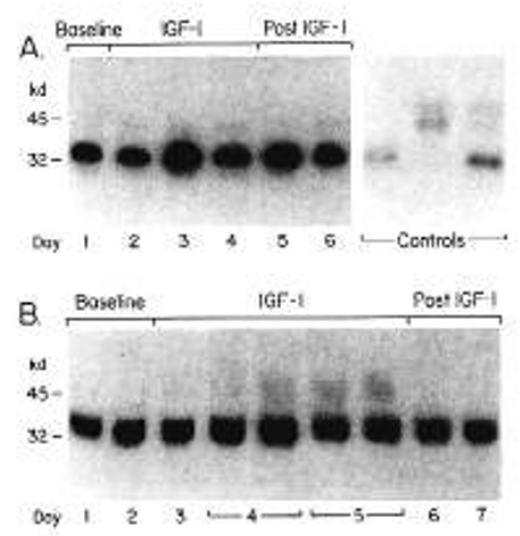

Figure 3. Effect of IGF-I infusions on IGFBP in two patients with leprechaunism. $A$, Ligand blot of plasma collected from FL-1. From left to right: the first day is preinfusion (baseline), $\mathrm{d} 2$ to 4 are during IGF-I, and $\mathrm{d} 5$ and 6 are post-IGF-I infusion. IGFBP- 2 levels are high for age, and no significant change was observed during the infusion. A modest increase in IGFBP-3 could be quantified when the ligand blot was exposed for a longer period of time (not shown). IGFBP from three age-matched controls are shown on the right. There is significant variability in the IGFBP profile, with IGFBP-2 levels being much lower than in our patients. $B$, Ligand blot of plasma collected from NC-2. From left to right: $d 1$ and 2 are pretreatment (baseline), d 3 to 5 are during IGF-I infusion, and the last two lanes ( $\mathrm{d} 6$ and 7) are postinfusion samples. No significant changes in the already high IGFBP-2 levels were noted, but a $50 \%$ increase in IGFBP-3 was measured with densitometry (d 4 and 5). binding protein for either patient, but a $50 \%$ increase in IGFBP-3 was observed in NC-2 during the IGF-I infusion (Fig. 3B). Only plasma of NC-2 was available for RIA of the IGFBP. Baseline concentrations of IGFBP-2 by RIA for $\mathrm{NC}-2$ were elevated at 1.08 and 1.47 (mean 1.28 ) $\mathrm{mg} / \mathrm{L}$ compared with normal, age-matched controls (O.26 \pm $0.08 \mathrm{mg} / \mathrm{L}$ ) and did not change significantly during IGF-I infusion $(1.09 \pm 0.31 \mathrm{mg} / \mathrm{L})$. In contrast, baseline IGFBP-3 concentration $(0.20 \mathrm{mg} / \mathrm{L})$ was low for chronologic age (normal $0.70-2.30 \mathrm{mg} / \mathrm{L}$ ) and increased to a maximal value of $0.38 \mathrm{mg} / \mathrm{L}$ (mean $0.28 \pm 0.09 \mathrm{mg} / \mathrm{L}$ ) during IGF-I infusion.

\section{DISCUSSION}

IGF-I promotes growth and differentiation of cells and mediates the anabolic effects of GH in animals (10) and humans (12). In hypophysectomized rats, IGF-I increases muscle protein content (10) and stimulates growth of cartilage and bone (20). IGF-I also decreases blood glucose, acting with approximately $6 \%$ the potency of insulin (21). In our two patients with leprechaunism, however, serum glucose remained elevated and no significant nitrogen-sparing effect was apparent after achieving supraphysiologic serum concentrations of IGF-I. We hypothesize that the ability of patients with insulin resistance to respond to IGF-I is determined by the degree and manner in which their underlying molecular defect in the insulin receptor gene interferes with normal insulin action. NC-2, who has a homozygous deletion of the insulin receptor gene, is predicted to have no insulin receptors (14). The specific molecular defect in FL-1 has not been determined, although mutations of the insulin receptor gene in other patients have been shown to impair receptor biosynthesis or transport to the cell surface, decrease the affinity of insulin binding, impair tyrosine kinase activity, or accelerate receptor degradation (22).

The inability of IGF-I to produce significant anabolic or glycemic effects in our patients differs from the findings of several recent reports in which IGF-I administration produced metabolic effects in patients with other syndromes of insulin resistance (23-25) and in patients with diabetes mellitus $(26,27)$. Kuzuya et al. (28) reported that s.c. injections of IGF-I (100-400 $\mu \mathrm{g} / \mathrm{kg}$ twice daily) for up to 16 mo in patients with type $A$ insulin resistance syndrome or congenital generalized lipodystrophy result in reduced glucose and insulin levels and sustained decreases in fructosamine and glycosylated $\mathrm{Hb}$. However, two of their patients with leprechaunism $(0.6$ and $7 \mathrm{y}$ old $)$ did not have improved glycemic control during IGF-I treatment despite decreased serum insulin concentrations and an apparent initial response to acute s.c. administration of IGF-I (100-300 $\mu \mathrm{g} / \mathrm{kg})$.

The failure of FL-1 and NC-2 to respond appropriately to IGF-I is enigmatic. Virilization and acanthosis nigricans, observed in most patients with this disease as well as our patients, may result from excessive concentrations of insulin acting through IGF-I receptors rather than from 
residual insulin receptor function $(29,30)$. The complete absence of insulin receptors in NC-2 supports this hypothesis. Although it is possible that insulin in our patients is acting through unknown mechanisms or interacts with an unidentified receptor (31), some IGF-I receptor signaling appears likely in these patients.

Several mechanisms should be considered to explain the failure of short-term infusions of IGF-I to exert effects in our patients. Their insulin receptor defects alone do not likely explain their failure to respond (Fig. 4, site 1 ), because they should have intact IGF-I receptors through which IGF-I would exert its effect. In NC-2, who is presumed to have no insulin receptors, we might anticipate impaired glycemic responses to IGF-I if some of the insulin-like effects of IGF-I are normally exerted through the insulin receptor. We would not, however, expect impaired anabolic responses, which should be mediated through the IGF-I receptor.

Attenuated or absent responses to IGF-I administration in our patients could therefore be secondary to defects in IGF-I binding (Fig. 4, site 3) or postreceptor signaling (Fig. 4, site 4). We assume that the IGF-I receptor is structurally normal because it is unlikely that our patients have two separate genetic defects. However, subnormal (7) as well as normal $(32,33)$ binding of IGF-I to the IGF-I receptor has been reported in patients with leprechaunism. Most likely, a defect in IGF-I postreceptor signaling (Fig. 4, site 4) explains the minimal responses in our patients. Myers et al. (34) showed that insulin and IGF-I share a common initial signaling pathway, at least to the level of interaction between insulin receptor substrate-1 and phosphatidylinositol 3-kinase. Signaling pathways distal to insulin receptor substrate-1

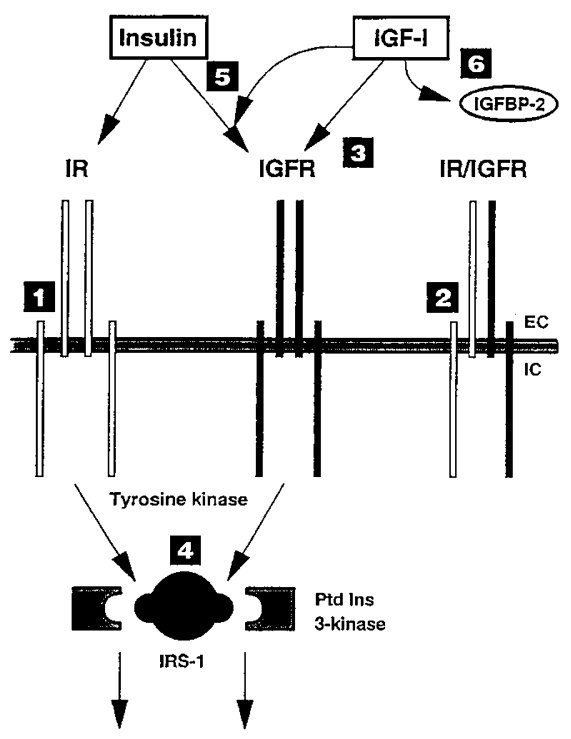

Figure 4. Possible mechanisms for absent insulin and IGF-I effects. $I R$, insulin receptor; IGFR, type I IGF receptor; IR/IGFR, insulin/IGF hybrid receptor; IRS-1, insulin receptor substrate-1; Ptd Ins 3-kinase, phosphatidylinositol 3-kinase; 1 , intrinsic insulin receptor defect; 2 , failure to form functional hybrid receptors; 3 , defective IGF-I binding to its receptor; 4 , postreceptor signaling defect; 5 , competitive inhibition of IGF-I binding by insulin; 6 , sequestration of IGF-I by IGFBP-2. diverge and probably explain the apparent differences in insulin and IGF-I receptor actions, but each may rely on one another for normal function.

Differences in the ability to form functional insulin/IGF hybrid receptors might also contribute to the heterogeneity in the response of insulin-resistant patients to insulin or IGF-I (Fig. 4, site 2). Although the signaling properties and biochemical effects of these hybrid receptors are not fully understood (35-37), failure of their formation in NC-2 would prohibit an IGF-I effect through this pathway.

Alternative explanations for the failure of our patients to respond appropriately to IGF-I infusion include competitive inhibition of IGF-I binding by extraordinarily high insulin concentrations (Fig. 4, site 5) and high circulating levels of unsaturated IGFBP-2 decreasing access of IGF-I to its receptor (Fig. 4, site 6). It seems unlikely that these mechanisms would prevent IGF-I actions completely when such high IGF-I serum values were achieved. The hypoglycemic response to infused IGF-I occurs within 1-2 h, often at lower doses than used here. It therefore seems unlikely that the duration of IGF-I infusion was too brief. However, calciuria increased in FL-1 during the IGF-I infusion, so we cannot exclude the possibility that more prolonged treatment would result in an anabolic effect.

Despite the absence of a glycemic or significant anabolic response to IGF-I, some changes were observed. Insulin and IGF-II concentrations decreased, whereas IGFBP-3 levels increased modestly in NC-2. Some of these effects may have been mediated via the IGF-I receptor. Because IGF-I and IGF-II are largely bound to the same IGFBP, it is probable that the decrease in IGF-II during the IGF-I infusion is the result of its displacement from IGFBP-2 and increased clearance from plasma. The increase in IGFBP-3 may be due to increased stability of this binding protein in the presence of increased IGF-I (38). The decrease in serum insulin appears to be relatively independent of changes in plasma glucose, and is thought to be mediated by a direct effect of IGF-I on pancreatic $\beta$-cells. Decreased insulin production occurs in rats in which euglycemia is maintained during IGF-I infusion $(39,40)$ and has also been shown in humans $(12,25)$. It is believed that this effect is mediated by the IGF-I receptor.

In summary, short-term i.v. infusions of IGF-I in two patients with extreme insulin resistance did not improve hyperglycemia or anabolism despite decreasing insulin concentrations. Our findings suggest that extreme insulin resistance due to defects in the insulin receptor may produce a postreceptor defect in IGF-I action.

\section{REFERENCES}

1. Donohue WL, Uchida I 1954 Leprechaunism: a euphuism for a rare familial disorder. J Pediatr 45:505-519

2. Rosenberg AM, Haworth JC, Degroot GW, Trevenen CL, Rechler MM 1980 A case of leprechaunism with severe hyperinsulinemia. Am J Dis Child 134:170-175 
3. D'Ercole AJ, Underwood LE, Groelke J, Plet A 1979 Leprechaunism: studies of the relationship among hyperinsulinism, insulin resistance, and growth retardation. J Clin Endocrinol Metab 48:495-502

4. Reddy SS, Lauris V, Kahn CR 1988 Insulin receptor function in fibroblasts from patients with leprechaunism: differential alterations in binding, autophosphorylation, kinase activity, and receptor-mediated internalization. J Clin Invest 82:1359-1365

5. Taylor SI, Kadowaki T, Kadowaki H, Accili D, Cama A, McKeon C 1990 Mutations in the insulin receptor gene in insulin resistant patients. Diabetes Care 13:257-279

6. Taylor SI, Kadowaki T, Accili D, Cama A, Kadowaki H, McKeon C, Moncada V, Marcus-Samuels B, Bevins C, Ojamaa K, Frapier C, Beitz L, Perotti N, Rees-Jones R, Margolis R, Imano E, Najiar S, Courtney F, Arakaki $\mathrm{R}$, Gorden P, Roth J 1990 Mutations in the insulin receptor gene in genetic forms of insulin resistance. Recent Prog Horm Res 46:185-217

7. Van Obberghen-Schilling EE, Rechler MM, Romanus JA, Knight AB, Nissley SP, Humbel RE 1981 Receptors for insulin-like growth factor I are defective in fibroblasts cultured from a patient with leprechaunism. $\mathbf{J}$ Clin Invest 68:1356-1365

8. Reddy SS, Kahn CR 1989 Epidermal growth factor receptor defects in leprechaunism. A multiple growth factor resistant syndrome. J Clin Invest $84: 1569-1576$

9. Massague J, Freidenberg GF, Olefsky JM, Czech MP 1983 Parallel decreases in the expression of receptors for insulin and insulin-like growth factor $I$ in a mutant human fibroblast line. Diabetes 32:541-544

10. Guler HP, Zapf J, Scheiwiller E, Froesch ER 1988 Recombinant human insulin-like growth factor I stimulates growth and has distinct effects on organ size in hypophysectomized rats. Proc Natl Acad Sci USA 85:4889-4893

11. Schoenle E, Zapf J, Humbel RE, Froesch ER 1982 Insulin-like growth factor-I stimulates growth in hypophysectomized rats. Nature 296:252-253

12. Walker JL, Ginalska-Malinowska M, Romer TE, Pucilowska JB, Underwood LE 1991 Effects of the infusion of insulin-like growth factor $I$ in a child with growth hormone insensitivity syndrome (Laron dwarfism). $N$ Engl $J$ Med 324:1483-1488

13. Clemmons DR, Smith-Banks A, Underwood LE 1992 Reversal of dietinduced catabolism by infusion of recombinant insulin-like growth factor I (IGF-I) in humans. J Clin Endocrinol Metab 75:234-238

14. Wertheimer E, Lu S, Backeljauw PF, Davenport ML, Taylor SI 1993 Homozygous deletion of the insulin receptor gene. Nature Genet 5:71-73

15. Copeland KC, Underwood LE, Van Wyk JJ 1980 Induction of immunoreactive somatomedin $\mathrm{C}$ in human serum by growth hormone: dose-response relationships and effect on chromatographic profiles. J Clin Endocrinol Metab 50:690-697

16. Davenport ML, Svoboda ME, Koerber KL, Van Wyk JJ, Clemmons DR, Underwood LE 1988 Serum concentrations of insulin-like growth factor II are not changed by short-term fasting and refeeding. J Clin Endocrinol Metab 67:1231-1236

17. McCusker RH, Clemmons DR 1988 Insulin-like growth factor binding protein secretion by muscle cells: effect of cellular differentiation and proliferation. $J$ Cell Physiol 137:505-512

18. Hossenlopp P, Seruin D, Segovia-Quinson B, Hardouin S, Binoux M 1986 Analysis of serum insulin-like growth factor binding proteins using Western blotting: use of the method for titration of binding proteins and competitive binding studies. Anal Biochem 154:138-143

19. Camacho-Hubner C, Busby WH, McCusker RH, Wright G, Clemmons DR 1992 Identification of the forms of insulin-like growth factor binding proteins produced by human fibroblasts and the mechanisms that regulate their secretion. J Biol Chem 267:11949-11956

20. Schoenle E, Zapf J, Hauri C, Steiner T, Froesch ER 1985 Comparison of in vivo effects of insulin-like growth factor I and II and of growth hormone in hypophysectomized rats. Acta Endocrinol (Copenh) 108:167-174

21. Guler HP, Zapf J, Froesch ER 1987 Short-term metabolic effects of recombinant human insulin-like growth factor I in healthy adults. $\mathrm{N}$ Engl $\mathrm{J}$ Med 317:137-140
22. Taylor SI, Cama A, Accili D, Barketti F, Imano E, Kadowaki H, Kadowaki T 1991 Molecular genetics of insulin resistant diabetes mellitus. J Clin Endocrinol Metab 73:1158-1163

23. Quin JD, Fisher BM, Paterson KR, Inone A, Beastall GH, MacCuish AC 1990 Acute response to recombinant insulin-like growth factor $I$ in a patient with Mendenhall's syndrome. N Engl J Med 323:1425-1426

24. Hone J, Skarulis M, Donaldson D, Cochran C Eastman R 1993 IGF-I treatment of a severely insulin-resistant child with short stature and diabetes mellitus. Program of the 75th Meeting of the Endocrine Society, Las Vegas, p 380(abstr 1319)

25. Schoenle EJ, Zenobi PD, Torresani $T$, Wender EA, Zachmann M, Froesch ER 1991 Recombinant human insulin-like growth factor I (rhIGF-I) reduces hyperglycemia in patients with extreme insulin-resistance. Diabetologia 34:675-679

26. Usala A-L, Madigan T, Burguera B, Sinha MK, Caro JF, Cunningham P, Powell JG, Cutler PC 1992 Treatment of insulin-resistant diabetic ketoacidosis with insulin-like growth factor I in an adolescent with insulin-dependent diabetes. N Engl J Med 327:853-857

27. Zenobi PD, Jaeggi-Groisman SE, Riesen WF, Roder ME, Froesch ER 1992 Insulin-like growth factor I improves glucose and lipid metabolism in type 2 diabetes mellitus. J Clin Invest 90:2234-2241

28. Kuzuya H, Matsuura N, Sakamoto M, Makino H, Sakamoto Y, Kadowaki T, Suzuki Y, Kobayashi M, Akazawa Y, Nomura M, Yoshimasa Y, Kasuga M, Goji K, Nagataki S, Oyashu H, Imura H 1993 Trial of insulin-like growth factor I therapy for patients with extreme insulin resistance syndromes. Diabetes 42:696-705

29. Cruz Jr PD, Hud Jr JA 1992 Excess insulin binding to insulin-like growth factor receptors: proposed mechanism for acanthosis nigricans. J Invest Derm 98(suppl):82S-85S

30. Moller DE, Flier JS 1991 Insulin resistance: mechanisms, syndromes and implications. N Engl J Med 325:938-948

31. Baker J, Liu J-P, Robertson EJ, Efstratiadis A 1993 Role of insulin-like growth factors in embryonic and postnatal growth. Cell 75:73-82

32. Kaplowitz PB, D'Ercole AJ 1982 Fibroblasts from a patient with leprechaunism are resistant to insulin, epidermal growth factor, and somatomedin C. J Clin Endocrinol Metab 55:741-748

33. Goodman PA, Shaccia P, Brunetti A, Wong K-Y, Carter JD, Rosenthal SM, Goldfine ID 1992 Growth factor receptor regulation in the Minn-1 leprechaun: defects in both insulin receptor and epidermal growth factor receptor gene expression. Metabolism 41:504-509

34. Myers Jr MG, Sun XJ, Cheatham B, Jachna BR, Glasheen EM, Backer JM, White MF 1993 IRS-1 is a common element in insulin and insulin-like growth factor-I signaling to the phosphatidylinositol 3'-kinase. Endocrinology 132:1421-1430

35. Treadway JL Morrison BD Goldfine ID Pessin JE 1989 Assembly of insulin/insulin-like growth factor I hybrid receptors in vitro. J Biol Chem 264:21450-21453

36. Soos MA, Whittaker J, Lammers R, Ullrich A, Siddle K 1990 Receptors for insulin and insulin-like growth factor I can form hybrid dimers: characterization of hybrid receptors in transfected cells. Biochem $\mathbf{J}$ 270:383-390

37. Mokham CP, Duronio V, Jacobs S 1989 Insulin-like growth factor I $\beta$-subunit heterogeneity: evidence for hybrid tetramers composed of insulin-like growth factor I and insulin receptor heterodimers. J Biol Chem 264:13238-13244

38. Zapf J, Schmid C, Guler HP, Waldvogel M, Hauri C, Futo E, Hossenlopp P, Binoux M, Froesch ER 1990 Regulation of binding proteins for insulin-like growth factors (IGF-I) in humans. Increased expression of IGF binding protein 2 during IGF treatment of healthy adults and in patients with extrapancreatic tumor hypoglycemia. J Clin Invest 86:952-961

39. Leaky JL, Vandekerkhove KM 1990 Insulin-like growth factor I at physiological concentrations is a potent inhibitor of insulin secretion. Endocrinology 126:1593-1598

40. Jacob R, Barrett E, Plewe G, Fagin KD, Sherwin RS 1989 Acute effects of insulin-like growth factor I on glucose and amino acid metabolism in the awake fasted rat: comparison with insulin. J Clin Invest 83:1717-1723 